\title{
The Effects of Metacognitive Strategy in Reading Expository Text
}

\author{
Yahya Othman ${ }^{1}$, Zamri Mahamud ${ }^{1} \&$ Noradinah Jaidi $^{2}$ \\ ${ }^{1}$ Faculty of Education, Universiti Kebangsaan Malaysia, Malaysia \\ ${ }^{2}$ University of Brunei Darussalam, Brunei Darussalam \\ Correspondence: Yahya Othman, Faculty of Education, Universiti Kebangsaan Malaysia, 43600 UKM Bangi, \\ Selangor, Malaysia. Tel: 603-8921-6231. E-mail: yahya.othman@ukm.edu.my
}

Received: July 22, 2014 Accepted: November 5, 2014 Online Published: December 21, 2014

doi:10.5539/ies.v7n13p102 URL: http://dx.doi.org/10.5539/ies.v7n13p102

\begin{abstract}
The purpose of this study is to evaluate the performance of student achievement during comprehension lesson using metacognitive strategy and examine the effects of the strategy used in reading and understanding expository text lessons. Besides, this study also identified metacognitive strategy used by students in all three reading processes (before reading, during reading and after reading). The research applied a quasi-experimental design. Research sample involved Standard 4 students from a government primary school in Muara Brunei District. Samples were divided into two groups, namely the experimental group and the control group. Each group involved 30 average-ranking students. Research results were analysed using independent t-test samples to assess the significant differences for mean of reading comprehension performance between control group and experimental group during pre and post-tests. Meanwhile One Way Ancova analysis was used to determine the effects of using metacognitive strategy during reading comprehension lessons. Based on the t-test analysis, there was a significant difference of reading comprehension performance between the score of experimental group and control group, $\mathrm{t}=12.96, \mathrm{p}<0.0$. The analysis of One Way Ancova data, $\mathrm{p}=0.00<0.05$ ( $\mathrm{F}$ " ratio $=493.22 / 2.25$ $=219.41 \mathrm{p}<0.05)$ also proved that the significant effects of metacognitive strategy usage on comprehension lesson. Overall, the metacognitive strategy used by the students in this study has proven to enhance students' understanding on the texts that they have read.
\end{abstract}

Keywords: metacognitive strategy, lesson, reading and comprehension, expository text, quasi-experiment

\section{Introduction}

\subsection{Background}

Reading is an important verbal skill that needs to be accomplished by students so that they can explore knowledge thoroughly (Yahya, 2010). In the process of reading a text, a reader has to understand the content, information, explanation or facts intended to be delivered by the author. In another words, the reading process can be complex because readers would have to involve the quality of thought for the purpose of understanding the text. Without understanding the text that has been read, the reader will not be considered to have mastered the reading skill (Korabiak \& Mete, 2004). This is because reading and understanding are constructive processes that support one another (Yahya \& Ghazali, 2010). For an effective reader, the capacity of understanding a text is seen as important even in primary school.

The $21^{\text {st }}$ century National Education System (SPN21) in Brunei Darussalam stated that the reading skill is not just perceived as a skill to pronounce and spell each word. The reading skill includes student's efficiency to read a sentence or a text smoothly as well as to correct pronunciation, intonation, and pauses. Emphasis is given on aspects such as understanding and reasoning of various materials, whether significantly or critically and analytically implied by using various reading techniques (Curriculum Development Department, 2009).

In addition, according to Yahya and Noradinah (2012) reading skill is not only limited to text comprehension skill and solely answering various comprehension questions, but the reading skill should also involve students' skills in evaluating information to solve problems, associating information with particular occasion, commenting and making assessments and conclusion based on information obtained from the reading materials.

Therefore, various learning strategies are used in reading and comprehension lessons. One of the strategies used is the metacognitive strategy. The purpose is to increase students' perceptions on the text being read thoroughly. 
The metacognitive strategy is not something new in the education field. According to Eilers and Pinkley (2006), this strategy is applied and taught to students to enhance the understanding of a text that has been read. The application of the metacognitive strategy during reading and comprehension lessons is also believed to help students to think methodically in all three levels of reading processes, namely before reading, during reading and after reading (Boulware-Gooden et al., 2007).

In El Koumy's (2004) research report, the metacognitive strategy also gets attention of language teachers and researchers throughout the world due to three things, namely (i) metacognitive knowledge can make a student to be a good thinker and student can learn according to time changes; (ii) by integrating metacognitive knowledge in language learning, it will be able to increase students' skills to control their own learning, and (iii) metacognitive awareness is an important basis for a more effective language learning. Therefore, the application of the metacognitive strategy should be given necessary consideration. From the conducted study, teachers can improve and alleviate further knowledge on metacognitive strategy in language teaching and learning.

\subsection{Statement of Problems}

The challenge of students being weak in reading and not being able to understand the contents being read is an issue that obstructs the language teaching and learning process (Yahya, 2009). Brunei Darussalam is not spared from the challenge. There are still complaints from primary and secondary school teachers who raised questions of students who cannot read and understand texts effectively (Tamam et al., 2011).

The analysis of examination results of Primary School Assessment (PSR) in 2010 for the Malay Language subject showed that one of the causes for students' weakness and failure in this subject is that there are still students who are weak in mastering reading. In the context of understanding questions, most students faced difficulties in answering questions, which involved high level of thinking skill. This can be proven when $78.4 \%$ of PSR 2010 candidates unable to answer comprehension questions involving analyses of phrases and giving opinions on the texts. An issue such as this should not be taken lightly because this problem could result in high number of student dropout rates in the education field.

Reading comprehension is also often being influenced by the teaching effectiveness factor (Yahya, 2009a). In a study carried out by Tamam et al. (2011), Malay Language teachers' teaching method, which is ineffective, becomes one of the factors that contributed to student difficulty of not being able to read and understand effectively. Furthermore most Malay language teachers conduct their reading and comprehension lessons by focusing solely on answering questions in textbooks. This is whereby the teachers would just ask students to read the phrases and discuss the texts that have been read. With that, the teaching process of reading comprehension text does not go on well.

This problem becomes more critical when the language teacher in charge does not expose the correct understanding techniques and strategies to students due to lack of experience and knowledge on reading strategies. According to Yahya (2009b), such reading comprehension lesson scenario does not lead to deep understanding of the students. Understanding will not happen by itself or by just pronouncing and providing meanings to each word in the materials read. Understanding will only happen if the readers are able to understand the meanings conveyed by the writer, forming relationships of the information read with the information known and then applied with what they have learnt along with real life experiences Yahya (2009). This is important because students, who are not exposed to the techniques and strategies of understanding the read text, will not able to practice ways to learn text reading and comprehension effectively. This problem is one of the contributing factors to the decline of students' academic achievement.

\subsection{Theoretical Research Framework}

The theory associated for the study is based on the Constructivism Theory as suggested by Tracy and Morro in McTavish (2008). According to Tracy and Morro, when constructivism theory is applied during reading lessons, metacognition plays a role to produce a constructive understanding when it comes to information acquisition that has been accessed and read. Through constructivism reading lessons too, students can build knowledge and concepts with the obtained information actively during reading and comprehension lessons. Students can form understanding through the reflection based on interactions with objects and ideas displayed in the texts (Yahya, 2008).

Based on the descriptions above, the theoretical framework for the study is taken and modified from the Students and Teachers Actively Reading Text (START) Reading Strategies Diagram in Scharlach (2008). The aspect that will be looked into is the application of metacognition strategy in reading and comprehension lessons comprising all three reading processes, namely before reading, during reading and after reading. Student will be able to build 
knowledge and concepts about obtained information from active text reading during reading and understanding lessons. The theoretical framework for this research is as in Figure 1.

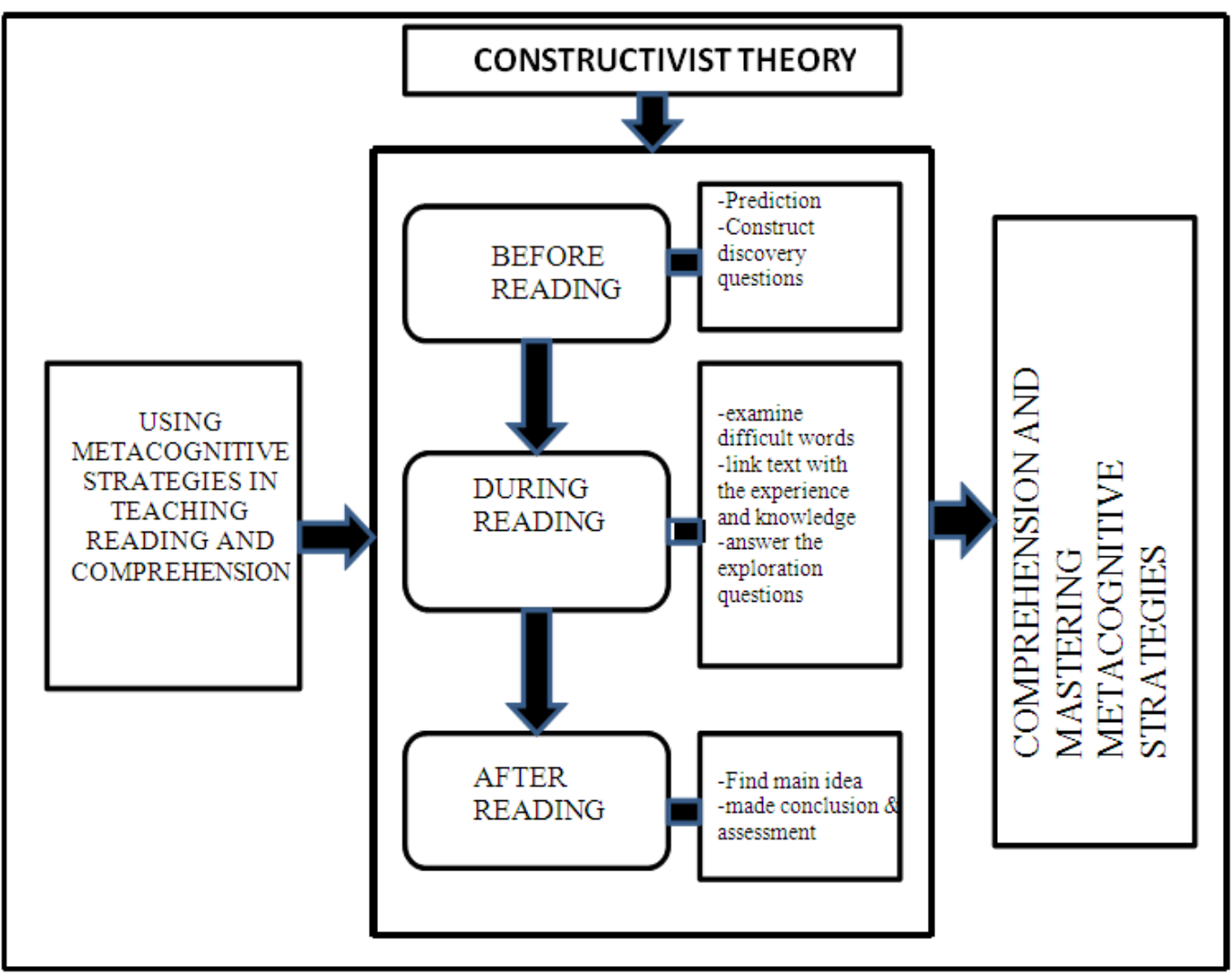

Figure 1. Theoretical framework on the research on the application of metacognitive strategy in reading and comprehension lessons

Figure 1 also shows the constructive application of metacognitive strategy during all three reading processes. Students will engage actively in guessing and constructing questions before the reading process begin. When reading the text on the other hand, students will continue to interact actively by examining difficult words, associating the text with knowledge and existing experiences and answering formulated questions. Meanwhile after reading, students will process information obtained from the text reading by making summary and overall assessment on key ideas that occur in the text. This is where the application of metacognitive strategy can help readers to build a constructive understanding in acquisition of information.

\subsection{Research Questions}

Based on the research objectives, this study is expected to answer the following questions:

Is there any significant difference for mean of comprehension performance among students who attended reading lessons using metacognitive strategy with students who attended reading lessons using conventional approach in pre-test?

Is there any significant difference for mean of comprehension performance among students who attended reading lessons using metacognitive strategy with students who attended reading lessons using conventional approach in post-test?

Is there any significant difference for reading comprehension lessons using metacognitive strategy in pre- and post-tests?

\subsection{Literature Review}

The effectiveness of metacognitive strategy in reading and comprehension lessons has been proven a lot from a few experimental studies conducted abroad. Reading and comprehension lessons are believed to be more effective with the application of metacognitive strategy. This has been mentioned in a study carried out by 
Houtveen and Grift (2007). Quasi-experimental research had been carried out aiming to assess the effect of metacognitive strategy application towards reading and comprehension lessons involving as many as 569 Standard 6 Dutch students. A total of 344 students were selected to join the experimental group, while the other 225 students were made as the control group sample. The experimental group was taught to read using the metacognitive strategy by teachers who had been given metacognitive skills training. Meanwhile, teachers who were involved in the control group were not given such training. Research results showed that the experimental group students' mastery of comprehension that had been exposed with metacognitive strategy in reading and comprehension lessons was higher compared to the control group. The results showed that the application of the strategy implemented by teachers during reading lessons is effective to increase students' understanding. Thus, this study clearly shows the importance of language teachers in applying metacognitive strategy so that it can be applied in lessons more effectively.

The same goes to Boulware-Gooden et al. (2007) who also carried out a study with the aim to assess the effectiveness of various metacognitive strategies in reading lessons to understand texts. Apart from that, this study also aimed to study the impact of metacognitive strategies on students' vocabulary expansion. This research involved Grade 3 students in two primary schools from west southern of United States that had been identified with moderate level of academic achievement. To achieve the objective of the study, the researcher decided of a school with intervention classes that taught reading using metacognitive strategies, while another school was turned into a control school sample that was not using metacognitive strategies. This study was carried out for a period of five weeks.

After both groups of students in Boulware-Gooden et al. (2007) were given comprehension tests using the same one expository text, Grade 3 students who followed the intervention reading classes using metacognition strategies were found to show positive results compared to students in the control school. Apart from showing a higher comprehension achievement, the intervention class students also had an increase in the mastery of vocabulary, which was better compared to students in the control group school. This decision clearly proves that comprehension lessons using metacognition strategies can help primary school students to understand texts, instantaneously enhance the thinking skills of students to learn vocabulary with methods that are more effective.

The metacognitive strategy is also found to be effective in helping students to understand all types of texts. This can be proven in a study carried out by Eilers and Pinkley (2006). The purpose of the study was to assess a project which practised reading and comprehension lessons of various text types using a few metacognition strategies involving utilisation of past knowledge associated with the reading texts, make presumptions on the materials read, and build information achieved from the reading materials. This project involved 24 Grade 1 students consisting of five Hispanic, one from the Asian/Pasific Island and 18 White students. After nine weeks of the project being carried out, comprehension tests results revealed that reading lessons using metacognition strategies explicitly could help to boost Grade 1 students' comprehension performances in various text types. The findings also showed the importance of using metacognition strategies in reading lessons, which should start from the early stage.

Caliskan and Sunbul (2011) looked into the consequences of using metacognitive strategy on students' academic achievement. This experimental study involved Gred 6 students in two primary schools in Turkey. A total of 42 students were made the research respondents and were divided into two groups, namely the experimental group and the control group. Each group contained 21 students. Students in the experimental group who were exposed to the application of metacognitive strategy for 15 weeks had shown increase in academic achievement compared to the control group who had not been given lessons on the application of metacognitive strategy. This study also proves that experimental group students can control their own learning and are more skilled in using the metacognitive strategy, which is suitable with their needs. The interview results also showed that the experimental group students could apply metacognitive strategy when they are learning at home.

Yahya et al. (2008) conducted a research related to metacognition involving eight university students. This research was intended to scrutinise comprehension process from the metacognitive perspective among university students. The research findings found that students have various metacognitive perspectives in the ability of interpreting comprehension towards texts. The perspective difference is also being influenced by reading strategy used, level of text difficulty, type of text and respondents' perception towards the read text.

Research done by Yahya et al. (2008) stated that among the strategies used by university students when readings were based on planning, monitoring and assessment. In planning the reading process, the metacognitive strategy used was writing important ideas. This strategy is widely used during the process of planning for reading to give impact on understanding. Meanwhile in monitoring while reading process, the metacognition strategy that was 
used to increase understanding was repeating the reading, referring to the dictionary, make mind mapping and omit sentences. In the last process, namely in evaluating reading, respondents were found to use metacognitive strategies like making presumptions, defend the understanding and make mental impression. In short, this study shows that readers are capable to improve their understanding quality by using strategy that is suitable with the ability.

Saemah and Phillips (2006) on the other hand carried out a study to examine the relationship of metacognition awareness, motivation and students' academic achievement. This study was carried out on 374 second year university students from five colleges in Universiti Kebangsaan Malaysia. Based on the data analysis gained from the questionnaires, metacognition awareness has a significant positive relationship on students' academic achievement. Based on the research findings, apart from motivation factor, students' knowledge and cognition regulation practice which encompasses planning, comprehension monitoring, assessment, debugging strategy and information management strategy play important roles in student learning process and would give impact on their academic achievement. The research findings prove that self-efficacy can influence the way students apply metacognitive awareness in their learning process.

\section{Research Methodology}

\subsection{Research Design}

This study applied the quasi-experimental method involving the quantitative approach. The experimental method design selected in this study was the pre-test design and experimental group post-test with control group (Sidek, 2002). The research design is displayed in Table 1.

Table 1. Design of pre-test and post-test of moderate group of students

\begin{tabular}{llll}
\hline Group & Pre-test & Treatment & Post-test \\
\hline Experimental & $\mathrm{T}_{1}$ & $\mathrm{X}$ & $\mathrm{T}_{2}$ \\
Control & $\mathrm{T}_{1}$ & & $\mathrm{~T}_{2}$ \\
\hline
\end{tabular}

Source: Design of Random Control Group, Pre-test and Post-test (Sidek, 2002).

Table 1 Note:

$\mathrm{X}$ : Treatment class given to experimental group using metacognitive strategy.

$\mathrm{T}_{1:} \quad$ Pre-test results for experimental and control groups.

$\mathrm{T}_{2:} \quad$ Post-test results for experimental and control groups.

\subsection{Research Respondents}

Research respondents consisted of Standard 4 students with moderate level of achievement aged between 10 to 11 years. Most of them were Malays studying in a government school in Brunei Muara district. A total of 60 respondents consisting of 32 male students and 28 female students were selected as research respondents.

\subsection{Research Instruments}

Research instruments included teaching preparation, reading texts, a set of comprehension tests, survey and observation form.

\subsection{Teaching Preparation}

There were two sets of teaching preparation used to implement every reading and comprehension lesson in this study. The teaching preparation sets were planned to teach the experimental group that emphasised the application of metacognitive strategy in reading and understanding the text that had been read (refer Appendix 2). Meanwhile in the second set of teaching preparation was to teach the control group to use conventional teaching method.

\subsection{Reading Texts}

There were five types of expository reading texts used in this study. Those reading texts were entitled 'Buah Naga Buah Istimewa'(Dragon Fruit Special Fruit), 'Misai Kucing', 'Pokok Getah (Hevea Brasiliensis) (Rubber Tree), Produk daripada Kayu Getah'(Product from Rubberwood) and 'Hidroponik' (Hydroponic). All the five reading texts were adapated from Standard 5 Malay Language textbook published by Star Publishing Pte. Ltd. 
(2009). Nevertheless, to serve the purpose and importance of this research, slight modification had been done in terms of vocabulary and also phrases of the five reading texts.

\subsection{Comprehension Texts}

A set of comprehension tests involved written tests given to the control group and the experimental group. In this study, the tests were given to both groups of students during pre-test and post-test. This test contained 15 items of subjective questions that required quick responses from students based on their understanding on the text that had been read. Each of the answer was given the value of 1 for the correct answer and 0 for the wrong answer.

\subsection{Data Analysis}

Quantitative data acquired from comprehension tests and sets of questionnaires were gathered and analysed using Statistical Package for the Social Science (SPSS) version 2.0. Data were elaborated by making mean comparison using t-test analysis. Independent variable t-test was used to compare mean of pre-test and post-test performances for control group and experimental group. Meanwhile analysis of covariance (One Way Ancova) was also used to determine the effect of metacognitive strategy application in teaching of reading comprehension. Significant level of all tests is $\alpha=0.05$.

\section{Findings and Discussion}

Research findings for each question are analysed and discussed as below:

\subsection{First Research Question}

Is there any significant difference for mean of comprehension performance among students who attended reading lessons using metacognitive strategy with students who attended reading lessons using conventional approach in pre-test?

Data gathered were analysed using Independent Sample t-Test (ISTT) to determine the significant difference of mean for reading comprehension performance among respondents who attended reading lesson using metacognitive strategy with respondents who attended reading lesson using conventional approach in pre-test. Research findings are in Table 2.

Table 2. T-test for mean difference of reading comprehension performance between experimental group and control group in pre-test

\begin{tabular}{llllll}
\hline Student Group & $\mathrm{N}$ & Mean & SD & t & $p$ \\
\hline Experimental & 30 & 6.47 & 2.11 & 0.879 & 0.383 \\
Control & 30 & 6.00 & 2.00 & & \\
\hline
\end{tabular}

Note: *Significance at 0.05 level.

Based on Table 2, it has been found that the mean of reading comprehension performance gained by experimental group is 6.47 and standard deviation (SD) is 2.11. Meanwhile control group only obtained a reading comprehension performance mean of 6.00 and SD 2.00. The mean difference between experimental group and control group in pre-test is only 0.47 .

The T-test analysis showed that there is no significance between mean score of experimental group and control group, $\mathrm{t}(60)=0.88, \mathrm{p}>0.05$. Therefore, the comprehension performance between both groups is the same before the treatment session. This similarity becomes an indicator that respondents in both groups have the same level of mastery in reading understanding before treatment session.

\subsection{Second Research Question}

Is there any significant difference for mean of comprehension performance among students who attended reading lessons using metacognitive strategy with students who attended reading lessons using conventional approach in post-test?

After six lesson sessions (treatments), respondents' comprehension performances based on the text read were measured through the post-test. The findings are as in Table 3. 
Table 3. T-test for mean difference of reading comprehension performance achievement between experimental group and control group in post-test

\begin{tabular}{llllll}
\hline Student Group & $\mathrm{N}$ & Mean & $\mathrm{SD}$ & $\mathrm{t}$ & $\mathrm{p}$ \\
\hline Experimental & 30 & 13.30 & 1.75 & 12.956 & $0.000^{*}$ \\
Control & 30 & 7.30 & 1.84 & & \\
\hline
\end{tabular}

Note: * Significance at 0.05 level.

Based on Table 3, the mean of reading comprehension performance gained by experimental group who attended reading lesson using metacognitive strategy is 13.30 and SD is 1.75 . Meanwhile control group who attended reading lesson conventionally gained comprehension performance mean of 7.30 and SD 1.84. Therefore, the mean difference between experimental group and internal control post-test is 6.00 .

The T-test analysis showed that there is a significant difference in mean for reading comprehension performance between the score of experimental group and control group, $t(60)=12.96, p<0.05$. This results of data analysis showed that comprehension performance for experimental group being exposed with reading lesson using metacognitive strategy is higher compared to control group that only been taught to use the conventional approach.

With the significant mean of comprehension performance, it clearly proves that reading lesson that uses metacognitive strategy can enhance comprehension performance at moderate level among students compared to conventional reading lesson. This is strengthened with the findings of earlier studies carried out by Eilers and Pinkley (2006) and Boulware-Gooden et al. (2007). Research results proved that the outcome of reading comprehension is better when students are exposed with metacognitive strategies during reading lessons.

Meanwhile, the control group respondents exposed with conventional reading lesson showed comprehension performance that is vastly low compared to the experimental group that have been exposed and given the skill to apply metacognitive strategy in reading and comprehension lessons. Without exposure on the strategy, this control group does not show a good performance in terms of their understanding towards the read text. In the study, it can be highlighted that students who have not been exposed and have not been given the skill to apply the metacognitive strategy in reading and comprehension lessons will be having problems in mastering the knowledge aspect. Therefore, the enhancement of students' understanding is influenced a lot by the strategy used when reading a text. Usually, the comprehension performance increased when students can apply the metacognitive strategy well when reading (Vehovec \& Bajsanski, 2006).

\subsection{Third Research Question}

Is there any significant difference for reading comprehension lessons using metacognitive strategy in pre- and post-tests?

In order to know the effect of teaching and learning of reading towards understanding using the metacognitive strategy, One-Way Ancova analysis was used. Through this analysis, the independent variable effect (treatment of reading and understanding lesson using metacognitive strategy) on dependent variable (post-test) can be decided by removing external variables (covariates) systematically. Through this analysis, influence of covariates (pre-test and external variables) towards statistically treatment could be controlled when the analysis was carried out. Therefore, bias on result or test result can be reduced. The result analyses for the test are displayed in Table 4. 
Table 4. One-way ancova analysis for experimental group- reading comprehension lesson in pre- and post-tests

\begin{tabular}{llllll}
\hline Source & Type III Sum of Squares & $\mathrm{df}$ & \multicolumn{2}{l}{ Mean Square $\mathrm{F}$} & Sig. \\
\hline Corrected Model & $598.468^{\mathrm{a}}$ & 2 & 299.234 & 133.116 & .000 \\
Intercept & 301.083 & 1 & 301.083 & 133.939 & .000 \\
Pre-test & 58.468 & 1 & 58.468 & 26.010 & .000 \\
Experimental Group & 493.218 & 1 & 493.218 & 219.411 & .000 \\
Error & 128.132 & 57 & 2.248 & & \\
Total & 7092.000 & 60 & & & \\
Corrected Total & 726.600 & 59 & & & \\
\hline
\end{tabular}

a. R Squared $=.824$ (Adjusted R Squared $=.817)$

b. Computed using alpha $=.05$

Through the One Way Ancova analysis in Table 4, there is a significant difference between mean for pre-test and post-test for experimental group $\mathrm{p}=0.00<0.05$ (F-ratio $=493.22 / 2.25=219.41 \mathrm{p}<0.05$ ). Therefore, the treatment of reading and comprehension lesson using metacognitive strategy gives a very positive effect on respondents' understanding in experimental group. Respondents in this group can enhance their comprehension performance in post-test compared to during pre-test (before respondents are exposed to the application of metacognitive strategy). Respondents' comprehension performances increased can also be seen in the study carried out by Houtveen and Grift (2007). In the research, it is showed that the mastery of students' understanding disclosed with metacognitive strategy in reading and comprehension lesson and understanding is higher compared to students who have been taught to read without using the strategy.

The effectiveness of metacognitive strategy application in improving comprehension performance can also be proven in the study by Fotovatian and Shokrpour (2007). Their research findings revealed that the application of metacognitive strategy affects reading and comprehension lesson performance. Student's comprehension performance is positive after being exposed to the application of metacognitive strategy (Kragler \& Martin, 2009). Apart from that, Cubukcu (2008) also found that the application of metacognitive strategy could enhance the particular student's understanding especially understanding expository texts. In the study, students who are taught to read using metacognitive strategy would enhance understanding on expository texts better and more effectively. Therefore, it is clear that reading and comprehension lesson treatment using metacognitive strategy gives a very good effect that could help to boost student's understanding.

\section{Summary and Conclusion}

In pre-test, it can be summarized that there is no significant difference of reading understanding performance between students of experimental group and control group. Both groups have the same level of understanding before treatment session is carried out. On the other hand, in post-test, it can be summarized that there is a significant mean difference of reading comprehension performance among students who attended reading lesson using metacognitive strategy with students who attended reading lesson using the conventional approach. With significant mean difference of comprehension performance, it shows that reading lesson using metacognitive strategy can enhance student's comprehension performance compared to conventional reading lessons.

Therefore, the application of strategies such as guessing, building questions, highlighting difficult words and referring meanings in dictionaries and connecting meanings with sentences according to the context of the reading material are important to increase understanding during the teaching of reading. Although the metacognitive strategies used by students in this study are only in basic form, however the application is very suitable for primary school students. According to Keene (2008), to make students to understand a particular text well, students do not have to use many metacognitive strategies. By using one or two suitable metacognitive strategies to read a text can give positive impact on the students' comprehension performance.

Furthermore, in reading lessons using metacognitive strategies, students are seen to involve actively. Students' involvement in using metacognitive strategies to understand texts has turned them into a more motivated and high confidence readers (Wigfield et al., 2008). Students also appear to enjoy activities like discussions with friends and flash back of reading material contents according to individual understandings. This activity can encourage them to interact with friends and teachers based on the reading materials that instantaneously can 
enhance understanding on the texts. Besides, these activities give opportunity for students to learn from one another in explaining their understanding.

Conventional reading lesson is completely different. Students are not exposed to any metacognitive strategy. The reading lesson is only linear and solely based on teachers. Students are requested to read the text, followed by answering comprehension questions individually. In this matter, students do not have the opportunity to use metacognitive strategy that could help them to plan, arrange and make assessment on their learning (Shaila \& Trudell, 2010). The result is that conventional reading lesson could not help to enhance student's comprehension performance.

In short, reading lessons using metacognitive strategies give very good effects towards student's understanding. The exposure among primary school students can be very suitable to train students to understand the text that they are reading more meaningfully (Jafari \& Ketabi, 2012; Karami \& Hashemian, 2012). This study concluded that reading lesson using the metacognition strategy can help to enchance students with moderate level of understanding on expository texts to understand better and more effectively compared to conventional approach.

\section{Reference}

Boulware-Gooden, R., Carreker, S., Thornhill, A., \& Joshi, R. (2007). Instruction of metacognitive strategies enhances reading comprehension and vocabulary achievement of third-grade students. Reading Teacher, 61(1), 70-77. http://dx.doi.org/10.1598/RT.61.1.7

Caliskan, M., \& Sunbul, A. (2011). The effects of learning strategies instruction on metacognitive knowledge, using metacognitive skills and academic achievement (Primary Education Sixth Grade Turkish Course Sample). Educational Sciences: Theory and Practice, 11(1), 148-153.

Cubukcu, F. (2008). Enhancing vocabulary development and reading comprehension through metacognitive strategies. Issues in Educational Research, 18(1), 1-11.

Curriculum Development Department. (2009). Kerangka dan panduan bagi kurikulum dan penilaian bahasa Melayu. Kementerian Pendidikan: Negara Brunei Darussalam.

Eilers, L. H., \& Pinkley, C. (2006). Metacognitive strategies help students to comprehend all text. Reading Improvement, 43(1), 13-29.

El-Koumy, A. (2004). Metacognition and reading comprehension: Current trends in theory and research. ERIC Document \#ED490569.

Fotovatian, S., \& Shokrpour, N. (2007). Comparison of the efficiency of reading comprehension strategies on Iranian University students' comprehension. Journal of College Reading and Learning, 37(2), 47-63. http://dx.doi.org/10.1080/10790195.2007.10850197

Houtveen, A. M., \& van de Grift, W. M. (2007). Effects of metacognitive strategy instruction and instruction time on reading comprehension. School Effectiveness and School Improvement, 18(2), 173-190. http://dx.doi.org/10.1080/09243450601058717

Jafari, D., \& Ketabi, S. (2012). Metacognitive strategies and reading comprehension enhancement in Iranian inetermediate EFL setting. International Journal of Linguistic, 4(3), 1-14.

Karami, S., \& Hashemian, M. (2012). The relationship between metacognitive strategies and reading comprehension in Iranian female L2 learners. International Journal of English, 2(4), 58-64.

Keene, E. (2007). Assessing comprehension thinking strategies. USA: Shell Education.

Korabiak, K., \& Mete, N. (2004). ICT in the discipline of reading. Retrieved January 27, 2010, from http://www.uoregon.edu / moursund /Digital Age1 /Project-Reading.pdf

Kragler, S., \& Martin, L. (2009). "I tried to make it not confusing by fixing it": describing six first graders' use of strategies to understand text. Reading Psychology, 30(6), 512-538. http://dx.doi.org/10.1080/02702710902733592

Saemah, R., \& Philips, J. A. (2006). Hubungan antara kesedaran metakognisi, motivasi dan pencapaian akademik pelajar universiti. Jurnal Pendidikan, 31, 21-39.

Scharlach, T. (2008). START comprehending: students and teachers actively reading text. Reading Teacher, 62(1), 20-31. http://dx.doi.org/10.1598/RT.62.1.3

Shaila, M., \& Trudell, B. (2010). From passive learners to critical thinkers: Preparing EFL students for university success. English Teaching Forum, 48(3), 2-9. 
Tamam, T., Zamri, M., \& Afendi, H. (2011). Faktor dan kesan masalah membaca dalam kalangan murid sekolah rendah kerajaan di Brunei Darussalam. Jurnal Pendidikan Bahasa Melayu, 1(1), 89-107.

Yahya, O. (2009a). Learning styles among university student from cognitive perspective. Paper presented at di International Conference on Teaching and Learning in Higher Education, The Legend Hotel Kuala Lumpur.

Yahya, O. (2009b). The application of metacognition strategies in reading process. The International Journal of the Humanities, 7(9), 145-153.

Yahya, O. (2010). Application of metacognition strategies and awareness when reading texts. The International Journal of Learning, 17(3), 457-472.

Yahya, O., \& Ghazali, M. (2010). Comprehension process in metacognitive perspective among university student. International Journal for Educational Studies, 2(2), 171-183.

Yahya, O., \& Noradinah, H. J. (2012). The Employment of Metacognitive Strategies to Comprehend Texts Among Pre-University Students in Brunei Darussalam. American International Journal of Contemporary Research, 2(8), 134-141.

Yahya, O., Ghazali, M., Shamsudin, A., \& Roselan, B. (2008). Proses pemahaman daripada perspektif metakognitif dalam kalangan Pelajar Universiti. Pertanika Journal of Social sciences dan Humanities, 16(2), 213-223.

\section{Copyrights}

Copyright for this article is retained by the author(s), with first publication rights granted to the journal.

This is an open-access article distributed under the terms and conditions of the Creative Commons Attribution license (http://creativecommons.org/licenses/by/3.0/). 